\title{
NATIVE PLANT PROJECT AT THE UNIVERSITY OF DUNDEE BOTANIC GARDEN
}

\author{
Alasdair Hood ${ }^{1} \&$ Clare Reaney $^{2}$
}

\begin{abstract}
This paper summarises the work undertaken at the University of Dundee Botanic Garden with regard to their native plants area and Target 8 of the Global Strategy for Plant Conservation since 2009. Propagation, micropropagation and growing techniques for ten native plant species are summarised and the successes and failures of these are discussed. The work demonstrates what can be achieved with even just a small amount of financial support.
\end{abstract}

\section{INTRODUCTION}

We present below a short summary of the work carried out as a result of funding totalling $£ 18,000$ received for a project to conserve Scottish native plants which was titled 'From Ben Lawers to the sea'. Funding came from a number of sources including the Friends of the University of Dundee Botanic Garden (UDBG), the Gannochy Trust and the Grant Trust. The project was designed to assist in the conservation of endangered plant species native to the upland Glens of Angus (Scottish Natural Heritage, no date) and the coastal areas of Tayside (Lloyd et al., 2002). The work has enabled us to enhance the native plants area with the creation of specialist habitats for rare and endangered species and by devising propagation techniques and growth and nutrition protocols for other selected species. As a result, these species can now be successfully propagated and planted out into the native plants area in the UDBG, but, and more importantly, hopefully also planted back into the wild in the future. This project runs in parallel with the refurbishment of the native plants area of the garden which was established in 1974 .

The funding described above meant that part-time horticultural technician Clare Reaney was given an additional forty days per year for three years from September 2009 to help progress this project, and additional funding was awarded to allow this work to continue for a fourth year to September 2013. This was a further 40 days of work funded by the Friends of UDBG who gave $£ 3,000$ and the Grant Trust who donated $£ 1,000$. We are now seeking further funding to continue this work for several more years.

The existing habitat types represented in the native plants area of the Garden include: Upland oak woodland, Scots Pine woodland, Juniper scrub, lowland heath, upland heath,

\footnotetext{
1. Alasdair Hood is Curator of the University of Dundee Botanic Garden.

Address: University of Dundee Botanic Garden, Riverside Drive, Dundee, DD21QH.

Email: A.d.hood@dundee.ac.uk

2. Clare Reaney is a Horticultural Technician at the University of Dundee Botanic Garden.

Address: As above.

Email: C.reaney@dundee.ac.uk
} 
montane cliff face and coastal dunes. The National Vegetation Classifications have been referenced as a guide (Joint Nature Conservation Committee, 2013) while making allowances for the microclimates at Dundee.

\section{THE FIRST THREE YEARS OF THE PROJECT}

An introduction of Rhinanthus minor (yellow rattle), collected at Tentsmuir in 2009, was made to an area of long grass and progress monitored for three years. The plan had been that this parasitic species would take nutrients from and reduce the vigour of the grass species, so benefiting the wild flowers. However, the yellow rattle did not succeed in such long and vigorous grass. So in order to establish an improved meadow area, further work will be needed to reduce the grasses before yellow rattle is sown again.

A team of staff from UDBG visited Glen Tanar in May 2012 in order to collect native Caledonian pine trees (Fig. 1) for transplanting into the shelterbelt at the Garden. These have established well and ten trees are being grown on in the UDBG nursery for future use. In order to acquire the plants, permission was sought from the Glen Tanar Estate via their forestry consultant as the area is a National Nature Reserve (NNR). This collection is the fourth distinct Pinus sylvestris collection in the Garden, previous plants having been grown on from seed out of Strathvaigh, Rothiemurchus and Black Wood of Rannoch.

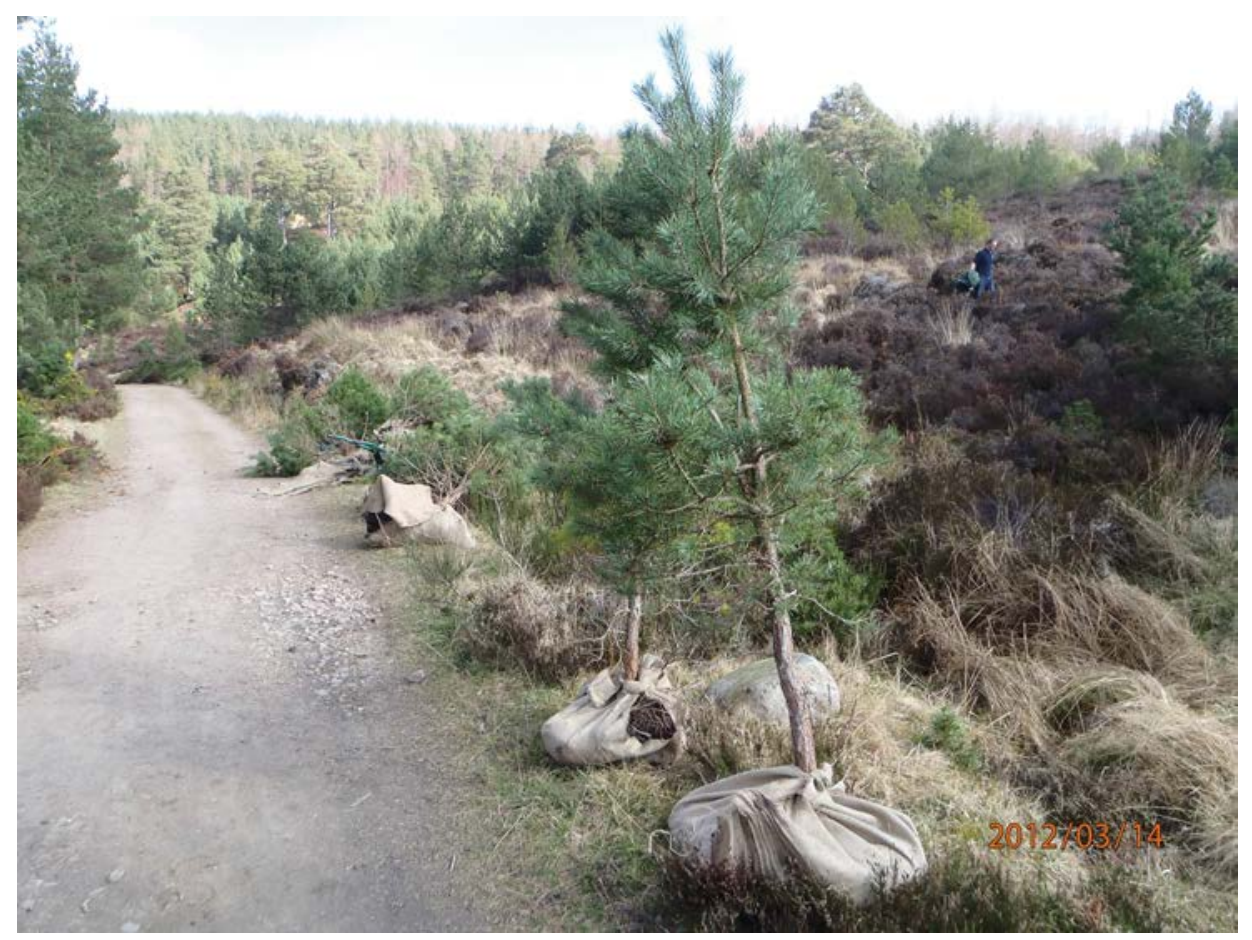

Fig. 1 Scots pines being collected for planting in UDBG in May 2012. Photo: Alasdair Hood. 
There have been other visits to see plants in their natural habitats including Parnassia palustris (bog star), Lycopus europaeus (gypsy weed) and Neottia ovata (syn. Listera ovata, common twayblade). We continue to develop links with the Dundee Naturalists and other local environmental groups.

In order to improve conditions for the plants that Clare has been growing, Garden staff thinned areas of the wood in autumn 2011. Work continues to cut back trees and overgrowing shrubs and this has improved the views and access from the main path. A new habitat area has been created for woodland edge perennials. Trees were felled, stumps removed and shrubs of Scottish provenance including Crataegus monogyna (hawthorn) and Prunus spinosa (sloe) were planted in November 2011.

Many of the woodland paths have become hazardous because of protruding tree roots and needed mulching to make them safe. Last winter, these areas became more inviting and attractive as more woodland flowers, such as Primula elatior (oxlip) and Hyacinthoides non-scripta (bluebell), were planted. As a result of the thinning of the woodland the bluebells and primrose were particularly good in spring 2012.

The primroses were divided and redistributed. Bluebell seed from the Isle of Eigg and Perthshire has now been introduced. The increased light levels have also led to the spread of more undesirable weeds, particularly Galium aparine (cleavers), so increased maintenance will be required until this area achieves a new balance.

In the third year of the project we refined the management of difficult to grow plants. In addition, plants acquired as single specimens have been propagated in order to secure their future and allow some experimentation with planting. Different methods of propagation have been tested and the levels of success or otherwise recorded. While growing these targeted plants in the nursery, the difficulties of maintaining a healthy population in the long term are becoming more apparent. For this reason we have found that it is important to continually propagate by seed and division in order to have enough plants to use for demonstration and display to the public. The removal of non-native plants, some of which are invasive, from the native plants area, particularly in the pond, is required twice a year and we hope to encourage the recruitment of volunteers to do this in future. To help coordinate this we have created a work diary for reference which includes the optimum times to remove pond plants and seed heads.

We have also been interested in establishing a population of Rhinanthus angustifolius (greater yellow rattle) at UDBG and, with cooperation from Scottish Natural Heritage $(\mathrm{SNH})$, it has been agreed that we will set up as a series of trial plots in the grass area which will be given different treatments. These include spraying one plot to kill off all vegetation, removing the top growth of another plot and leaving various lengths of grass on others. This trial has yet to come to fruition although we are planning to do this in autumn 2013.

One of the long-term goals for UDBG has been the creation of a peat bog to increase the habitat types represented within the native plants area. One of the reasons for this is that Scotland has one of the largest areas of peat bog in Europe and it has been decided to demonstrate this habitat type. This area would provide a place to grow sphagnum moss 
and insectivorous plants. A potential opportunity presented itself in March 2011 when staff visited a wind farm site in the north of Scotland with a view to getting some of the peat displaced from the site during construction to help with the creation of the peat bog. The company were more than willing to allow us to take material, but unfortunately the transportation costs and the distance proved too great. We will keep looking for development sites where peat could be removed and will open discussions about obtaining a quantity of it. We have estimated that the cost of developing a peat bog would be in the region of $£ 15,000$.

\section{Lathyrus japonicus ssp. acutifolius (sea pea) in Angus}

Because of the continual erosion of parts of the Angus coastline the existing populations of Lathyrus japonicus ssp. acutifolius (sea pea) (Fig. 2) are now restricted to a small area of rock armour (rock encased in large wire baskets for dune stabilisation) near the town of Carnoustie, 11 miles from Dundee, an area well known for its golf courses (Loizou, 2006). The Golf Environmental Organisation, an organisation which advises golf courses about environmental issues, assisted Alasdair Hood to collect seed and grow on new plants which were planted back within range of the existing colony. Unfortunately, the majority of the first replacement plantings were swept away by winter storms, except for a few plants near the rock armour.

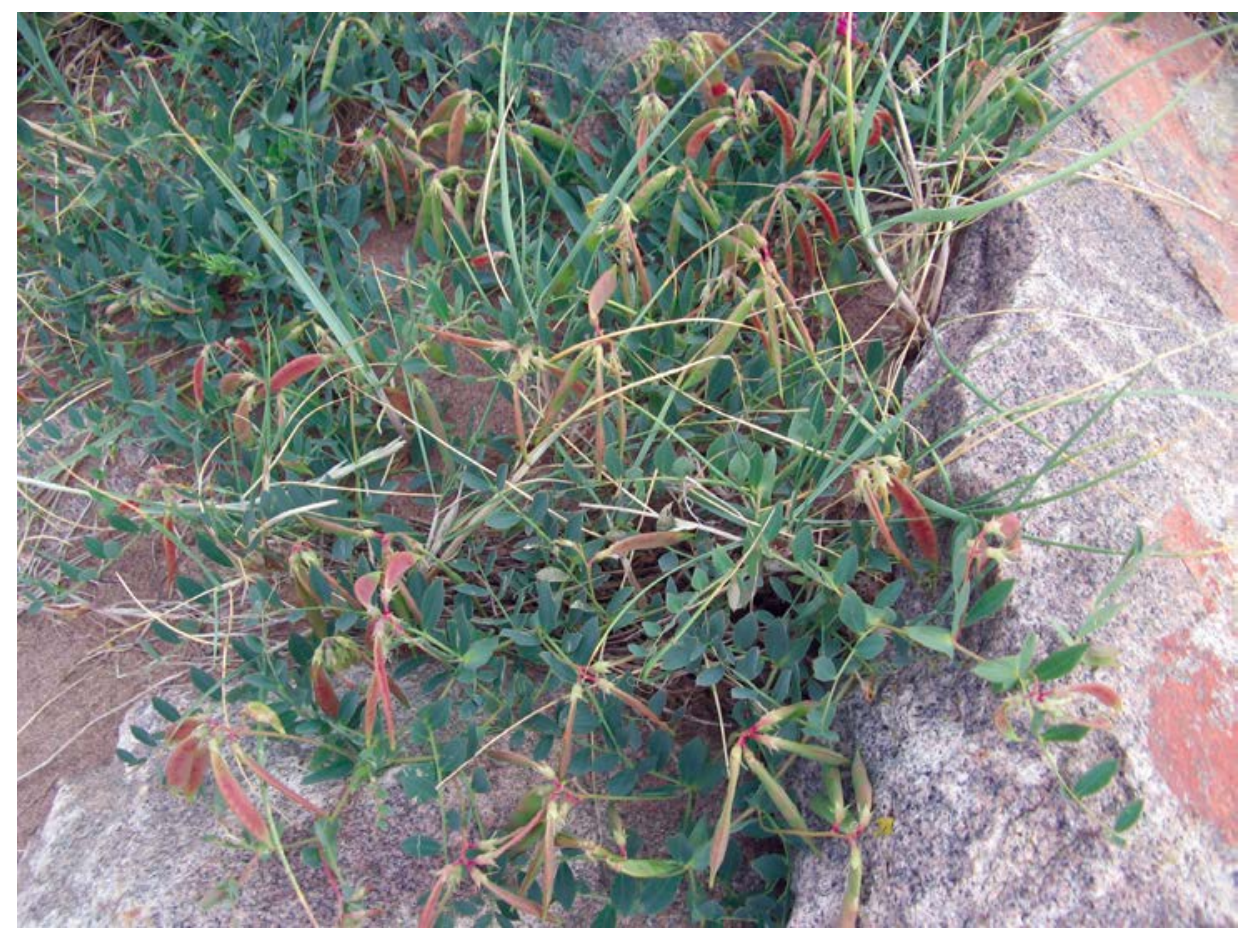

Fig. 2 Lathyrus japonicus ssp. acutifolius (sea pea). Photo: Alasdair Hood. 
In collaboration with SNH it was agreed to try planting seedlings of sea pea at Barry Buddon (Fig. 2). This site is part of a Site of Special Scientific Interest (SSSI) situated on the Ministry Of Defence (MOD) firing range and is thus not open to the general public, so the plants may have a good chance of establishment.

This planting was carried out in July 2012 by three UDBG staff. The success of this planting was monitored in June 2013 and all the plants are thriving. Angus Council has installed more rock armour at the mouth of the Barry Burn which has provided new planting sites where plants have also been observed growing well. Seed was collected from these Lathyrus plants in September 2013.

\section{MICROPROPAGATION}

The Friends of UDBG helped to fund a supplementary project to develop micropropagation techniques for a number of Scottish native plants. This has been carried out for two years and is now beginning to show some results. The work is being undertaken by the Shetland Amenity Trust in Lerwick which has a small micropropagation facility. In September 2012, they reported the following:

- Cicerbita alpina: Original material of root sections failed, so seed from open pollinated plants from RBGE was used as the source material: 54 potted into compost, $1 \mathrm{st}$ batch now in 1-litre pots, 2 nd batch in $9 \mathrm{~cm}$ pots; 10 in jars nearly ready to transfer to compost; 27 ready to go into final rooting medium, with another 50 still in in vitro.

- Silene suecica: 8 potted; c. 20 in jars with rooting medium, nearly ready to be potted; c. 120 in vitro and already rooting - should be ready to transfer to compost in very small pots. The fine roots need more grit and perlite than C. alpina.

- Silene nutans: Only able to overcome contamination problems from leaf cuttings fairly recently; currently about half of 60 plants in vitro and they are looking good.

- Astragalus alpinus: The most problematic one; only 1 plant in vitro from cutting; 2 plants from seed, but a few more germinating. We suspect there may be an issue here with the leguminous nature of the species - they may require a reduced nitrate solution in the medium to improve rooting.

Alasdair Hood collected 100 micropropagated plants of Cicerbita alpina and 20 of Silene suecica from Shetland in May 2013. We intend to plant these out in the native plants area and monitor their growth.

The Shetland Amenity Trust has, from May 2013, concentrated on propagating Silene nutans (Fig. 3) which are making good progress in vitro and S. suecica which are also looking healthy. Propagation experiments for Astragalus alpinus have been suspended until more resources are available. Fig. 4 shows the plants in test tubes in the growth cabinet. 


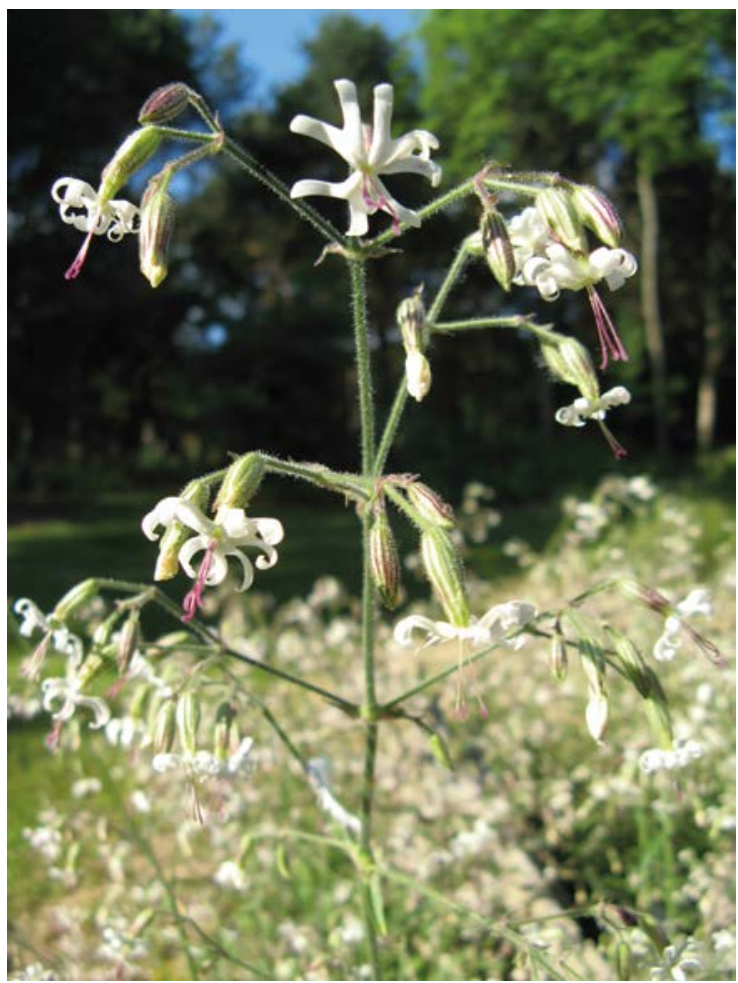

Fig. 3 Silene nutans. Photo: Clare Reaney.

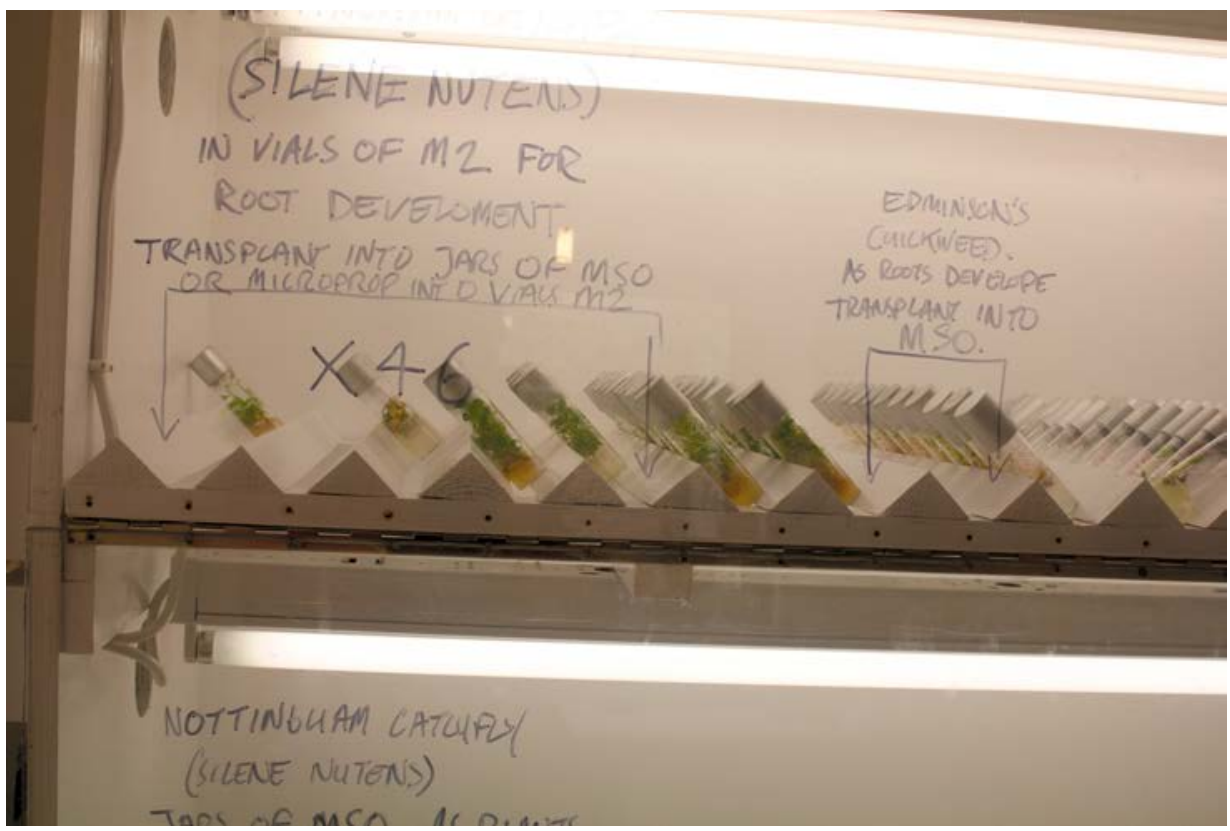

Fig. 4 Plants in the growth cabinet. Photo: Alasdair Hood. 


\section{OBJECTIVES FOR 2012-2013 WITH ADDITIONAL FUNDING RECEIVED}

- Continue to grow and monitor Scottish plants at UDBG and plant them in the native plants area

- Seek further funding to gain more experience in growing threatened native plants

- Introduce woodland edge mixes to the broad-leaved woodland areas

- Improve the native pond by removing non-native species

- Collect fresh seed from the wild

- Run a native plants workshop to engage the public about threatened native species

- Continue to explore the possibilities of establishing a peat bog at UDBG

- Seek finance for DNA analysis to help determine genetic loss in collections and to explore genetic differences between European and Scottish populations

- Increase micropropagation of the threatened species

\section{EXPERIENCE GAINED FROM THE PROJECT}

Table 1 summarises the experience gathered in the course of this project of the plants grown in UDBG since 2009. It can be seen that there is often more vigour found in seed from European sources (acquired through indices seminum of a range of botanic gardens) and we suggest this may be partly due to inbreeding depression in the Scottish populations (Alexander, 2006).

While the seed of Silene suecica is often plentiful and germinates easily, the seedlings take several months to develop into strong growing plants and one group of newly pricked-out seedlings was lost after a torrential downpour.

In contrast, seed production of Astragalus alpinus is limited and the seeds are slow and erratic to germinate. Some germination occurred three years after sowing, however this delayed germination is common in legumes. The seedlings remain tiny for the first year and during this stage are very vulnerable to slugs; in contrast, seedlings of the related A. danicus are rarely eaten by slugs. Therefore one can speculate that even small changes in the native habitat such as a reduction in snow cover or changes in grazing patterns would have an effect on such small plants.

Erigeron alpiniformis and Silene suecica are now being grown from seed that has been isolated for three generations. It would be beneficial to collect fresh seed from wild populations to maintain a healthy population and genetic mixture in the population at UDBG. While we are conscious of this need, staffing constraints have prevented the organisation of permission to collect (from $\mathrm{SNH}$ ) as well as the collection of the seeds itself.

Other propagations include Paris quadrifolia (Fig. 5), a slow-growing woodland plant, and the whorled Solomon's seal, Polygonatum verticillatum (Fig. 6). The latter is found only at one site in Scotland, in Perthshire. UDBG has two accessions and seed collected from these plants have grown well.

In total, 55 new native plant species have been introduced to UDBG. Thirty of these have been collected directly from the wild. Other species have been acquired from 


\begin{tabular}{|c|c|c|c|c|c|}
\hline Plant name & $\begin{array}{c}\text { Provenance } \\
\text { of seed }\end{array}$ & Method of propagation & Success & $\begin{array}{l}\text { Planted } \\
\text { out }\end{array}$ & $\begin{array}{c}\text { Further action } \\
\text { for } 2013\end{array}$ \\
\hline $\begin{array}{l}\text { Astragalus } \\
\text { alpinus }\end{array}$ & Finland & $\begin{array}{l}\text { Seed slow and require } \\
\text { protection from slugs. } \\
\text { Sow in pea tubes. }\end{array}$ & Good & No & $\begin{array}{l}\text { Plants in third } \\
\text { year in nursery }\end{array}$ \\
\hline A. alpinus & Scotland & $\begin{array}{l}\text { Seed slow and erratic } \\
\text { to germinate. Mature } \\
\text { plants devoured by } \\
\text { slugs. }\end{array}$ & Moderate & No & $\begin{array}{l}\text { Plants in second } \\
\text { year, healthy }\end{array}$ \\
\hline A. danicus & Scotland & $\begin{array}{l}\text { Seed germinates well in } \\
\text { pea tubes }\end{array}$ & Good & Yes & $\begin{array}{l}\text { Continue to } \\
\text { grow from seed }\end{array}$ \\
\hline $\begin{array}{l}\text { Cerastium } \\
\text { alpinum }\end{array}$ & Scotland & $\begin{array}{l}\text { Seed self-seeds in } \\
\text { nursery. }\end{array}$ & Good & Yes & \\
\hline $\begin{array}{l}\text { Cicerbita } \\
\text { alpina }\end{array}$ & Germany & $\begin{array}{l}\text { Division and seed which } \\
\text { self-seeds in Garden }\end{array}$ & Good & Yes & \\
\hline C. alpina & Scotland & $\begin{array}{l}\text { Root cuttings from } \\
\text { RBGE }\end{array}$ & No & No & $\begin{array}{l}\text { Try again with } \\
\text { larger roots }\end{array}$ \\
\hline $\begin{array}{l}\text { Erigeron } \\
\text { alpiniformis }\end{array}$ & Iceland & $\begin{array}{l}\text { Seed kept in refrigerator } \\
\text { still germinated after } \\
\text { three years }\end{array}$ & Good & $\begin{array}{l}\text { Yes - } \\
\text { self-seeds }\end{array}$ & \\
\hline $\begin{array}{l}\text { Lathyrus } \\
\text { japonicus ssp. } \\
\text { acutifolius }\end{array}$ & Scotland & $\begin{array}{l}\text { Seed pre-soaked in } \\
\text { warm water and sown in } \\
\text { pea tubes }\end{array}$ & Good & Yes & $\begin{array}{l}\text { Planting at } \\
\text { Carnoustie in } \\
2013\end{array}$ \\
\hline $\begin{array}{l}\text { Oxytropis } \\
\text { campestre }\end{array}$ & Scotland & Seed & Good & Yes & $\begin{array}{l}\text { Try basal } \\
\text { cuttings in } \\
\text { spring }\end{array}$ \\
\hline $\begin{array}{l}\text { Saxifraga } \\
\text { hypnoides }\end{array}$ & Scotland & Plants & Good & Yes & Division or seed \\
\hline Silene nutans & Scotland & Seed & Good & Yes & \\
\hline S. suecica & Iceland & $\begin{array}{l}\text { Seed easy to germinate, } \\
\text { slow to develop }\end{array}$ & Good & Yes & \\
\hline S. suecica & Scotland & $\begin{array}{l}\text { Division of plants delays } \\
\text { flowering and prolongs } \\
\text { life span }\end{array}$ & Poor & No & $\begin{array}{l}\text { Prevent } \\
\text { flowering; try } \\
\text { division }\end{array}$ \\
\hline
\end{tabular}

Table 1 A summary of propagation and cultivation experience of plants grown in UDBG since 2009.

nurseries dedicated to plants of Scottish provenance, particularly Scotia Seeds and Alba Tree Nursery.

Experiments have been carried out on the propagation of Silene suecica which was propagated by division in July 2012. The plants were dissected with a sharp knife and struck into a 50:50 peat/perlite rooting medium. The cuttings were placed in a heated propagator with shading. Twenty new plants rooted within one month. 


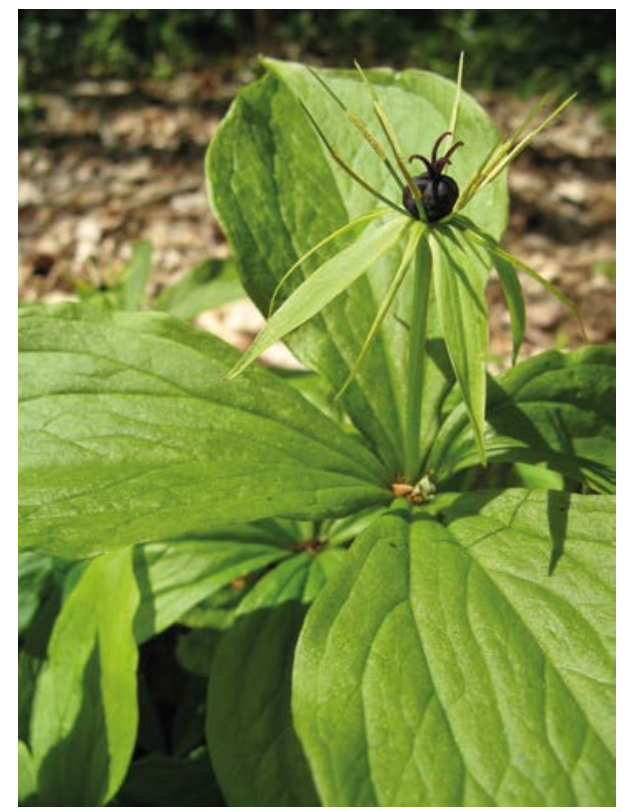

Fig. 5 Paris quadrifolia. Photo: Clare Reaney.

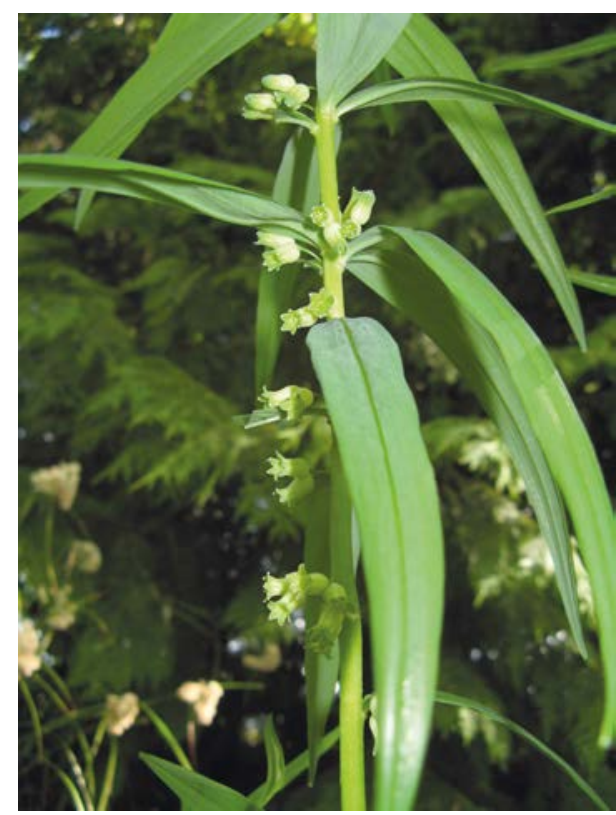

Fig. 6 Polygonatum verticillatum.

Photo: Clare Reaney.

\section{INTERPRETATION OF THE PROJECT}

In 2012, an exhibition involving photography and original artwork was produced. The Dundee Naturalists Society provided photographic material and a local artist produced watercolour paintings of the plants growing at UDBG. As the plant species were rare it was difficult to find good-quality pictures. The exhibition, entitled 'From the Glens to the Sea', was exhibited in three locations: at the Visitor Centre in UDBG, at the Glen Doll Visitor Centre in Angus and for three weeks at the University of Dundee Tower Building in central Dundee.

As the Garden has membership of the Botanical Society of the British Isles (BSBI) we had publicity support and access to experts within BSBI to help us prepare the information boards which formed part of the exhibition. The exhibition attracted some good publicity and was seen by a wide audience, which has raised awareness of the conservation work going on at UDBG.

In July 2013, a visitor information leaflet was produced with a map showing the different habitat types that the native plants area demonstrates. Interpretation boards to accompany the plantings in the native plants area have also been produced (Fig. 7). 


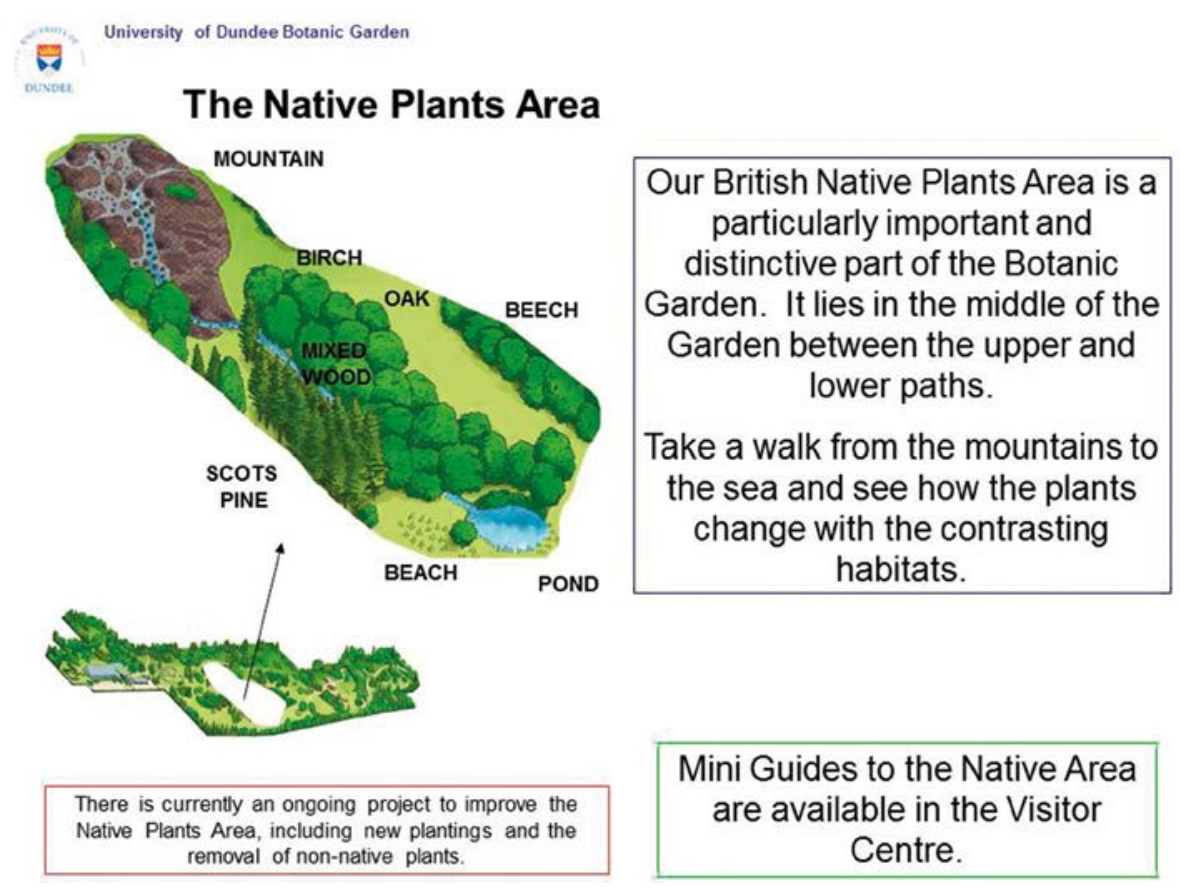

Fig. 7 Interpretation board installed in the native plants area of UDBG. Created by Neil Paterson.

THE FUTURE OF THE PROJECT

The Friends of UDBG have offered $£ 4,000$ to help continue this project for a fourth year. This amount includes a $£ 1,000$ donation from the Grant Charitable Trust to the Friends for this purpose. At an approximate cost of $£ 100$ per day, this provides 40 days of work starting in September 2012 and expected to finish at the end of August 2013. It is anticipated that this will be distributed as four days per month, with the exception of November, December and January, and six days per month in April and May. Additional funding is being sought to expand the duration of this valuable project.

As part of our commitment to the native plants area Alasdair Hood will devote time to the management and development of the project. Neil Paterson, UDBG Education Officer, will commit 40 hours to the production of interpretation and a mini guide. The two full-time gardening staff at UDBG will ensure that basic maintenance levels are achieved and will use volunteers when available to help maintain the plants and redeveloped areas.

The following could be achieved via student projects:

- Focus on a group of related plants: for example, a detailed comparison of Erigeron alpiniformis and E. acer (which occur on mountain and shore habitats respectively). They could look at all the factors that influence them and set up controlled areas to check the rate of spread. They could also measure the amount 
of seed set, seed viability, tolerance of $\mathrm{pH}$ and trial resistance to grazing and trampling

- Focus on a plant with particular insect associations such as Anthyllis vulneraria (kidney vetch)

- Compare the UDBG native plants area with another local site and examine the plant associations

\section{ACKNOWLEDGEMENTS}

This project has been supported by the Friends of UDBG, who in turn received financial support from the Gannochy Trust and the Grant Charitable Trust. Clare Reaney and Alasdair Hood would like to thank all of them for the kind support which has allowed this project to develop. We would also like to thank the many volunteers who have given their time over the years to help keep the garden weed-free.

\section{REFERENCES}

ALEXANDER, L. (2006). Plantlife dossier: Cicerbita alpina Available online: www.plantlife. org.uk/uploads/documents/cicerbita_alpina_dossier.pdf (accessed August 2013).

LLOYD, C., ANDERSON, A., ANDERSON, B., BISSET, L., BORLAND, C., BORLAND, S., BURNS, C., CLARK, E.J., COUTTS, P., COWAN, D., FLEMING, J., GARSON, L., GOATER, R., GUTHRIE, R., HALL, C., HELMSLEY, D., HENDERSON, B., HILL, S., HOUSE, S., HUGHES, B., KIRKLAND, P., LESLIE, G., LINDSAY, H., LLOYD, I., LOCKETT, R., LONG, J., MCDONALD, I., MURRAY, A., PAWLEY, L., REEKIE, B., ROSS, A., SIMMONS, M., SMITH, I., STEPHEN, A., STEWART, M., STONEMAN, U. \& TAYLOR, N. (2002). Tayside Biodiversity Action Plan. Available online: www.angus.gov. uk/biodiversity/actionplan.htm (accessed August 2013).

LOIZOU, T. (2006). Re-introduction of Lathyrus japonicus at Elliot Links SSSI in Angus: ecological and management aspects. SNH commissioned report no. 200 (ROAME No. F02 LHo9). Available online: www.snh.org.uk/pdfs/publications/commissioned_reports/ Report\%20No200.pdf (accessed September 2013).

SNH (no date). Corrie Fee National Nature Reserve - The Reserve Story. Available online: www. snh.org.uk/pdfs/publications/nnr/corrie_fee_nnr_story.pdf (accessed August 2013) 
